\title{
Tripartism in Comparative and Historical Perspective
}

\author{
Richerd Croucher and Geoffrey Wood
}

\begin{abstract}
This article provides an overview of interpretive approaches to the historic development of tripartism globally. Locating tripartism firmly within four broad approaches to labour management, we seek to qualify those strands that regard the phenomemon as lacking in current relevance. We argue that elements of post-war compromises persist and indeed have been recently initiated even if in many societies they exist in dilute form. Thus, the concept's very elasticity and polyvalence ensures its continued relevance, in turn calling for further examination of its historic evolution.
\end{abstract}

Keywords: Tripartism; comparative; transnational history

Interest in state-led co-ordination of trade unions and employers' bodies, and notably in social and wage pacts in Western Europe has been considerable in the Twenty-First Century ${ }^{1}$. Simultaneously, there has been discussion of the diminished scope and intensity of the tripartite political exchanges characteristic of corporatism in its earlier post-1945 incarnations, and questioning of the continued viability of more limited forms of interaction even in densely-institutionalised Europe ${ }^{2}$. Outside of Europe, the evolution of different forms of national institutional dialogue has attracted only limited interest. It is in this context, where the nature of national institutional dialogue on employment and social issues is still under discussion and its future is also called into question, that this special issue presents a range of contributions on the history of tripartism that allow development of a secular perspective on these debates. Historical concerns are frequently stimulated by those of the present and this is especially the case in contemporary history. ${ }^{3}$ Anglo-Saxon historians may feel that the age of tripartism is at an end, but the contributions within this issue show that although this may accurately reflect current perceptions, tripartism continues, albeit often in weak forms, in other national and transnational contexts; its history therefore retains contemporary resonance.

In our present age, it is commonly assumed that the relative power of employers has increased at the expense of government - the central co-ordinating actor in tripartism and organized labour. Within the firm, not only workers, but also traditional managers have been displaced by assertive investors and allied to them, a new managerial class that has little emotional capital sunk in the firm other than as a vehicle for shareholder value maximization or release, and personal enrichment. From the business historian's viewpoint, these assumptions raise a number of issues surrounding long term trends and diversity in the nature of the capitalist ecosystem within which tripartism is located. In this connection, there are four alternative points of view on broad approaches to labour management. The first, rooted in the then apparent solidity of the British postwar tripartite settlement, was that the incorporation of labour's institutions was structurally essential to the state's role in avoiding or genuinely resolving crises. ${ }^{4}$ The second sees tripartism as very much an historical exception, representing to a large extent a product of a very specific set of historic circumstances around the Great Depression and the post-World War Two long boom. ${ }^{5}$ The third, a variant of the second, would see historic compromises 
between the state, employers and workers as a reflection of the thirty year period of relative global prosperity and growth which had deeper historic roots stretching back at least into the Nineteenth Century. ${ }^{6}$ The fourth highlights national diversity in global capitalism and views the labour management options adopted according not only to temporal trends but also to such dimensions as space, scale, and global centre-periphery relations. ${ }^{7}$ The latter view implies that elements of post-war compromises may persist, even if, within many of the advanced societies, they do so in dilute form. ${ }^{8}$

\section{Tripartism as historical exception}

Tripartism almost by definition requires a polity within which élites are prepared to institutionalize compromise with labour. Yet a very wide and diverse body of thinking from across the political spectrum suggests that the normal condition of society for centuries has been characterized by labour repression, entailing the extraction by relatively small élites of the bulk of any surplus generated. The great theorist of American slavery, John Calhoun, defended it through the assertion that labour coercion was encountered in all societies, and that modern slavery represented a relatively benign form in that it ostensibly encompassed welfare commitments on the behalf of masters which were absent under the impersonal relations of wage labour. ${ }^{9}$ This view, of course, challenges the argument that labour coercion both under slavery and more widely is often irrationally cruel since human property was often wilfully damaged by its owners. ${ }^{10}$

More generally speaking, it can be argued that élites are extremely reluctant to compromise even when the alternatives are social disorder or war. Marx believed that though repression had hitherto been universal, general emancipation was possible, and, indeed that wage labour already represented an improvement on any previous form of production. He was also notoriously skeptical of the possibility of meaningful reform and class compromises. Why then, were the great compromises of the post war settlement constructed? The weight of opinion here is that they reflected a highly specific set of circumstances. In the Anglo-Saxon economies, labour had been hugely strengthened by rearmament, war and an anti-fascist ideological consensus. The inter-war Great Depression and the rise and collapse of fascism compromised the legitimacy of defenders of untrammeled corporate power, and highlighted the exhaustion of policy alternatives short of class compromise. A policy alternative that had been advocated by organized labour in Germany and Britain since the late Nineteenth Century, that is the partial integration of unions into national government decision making, was therefore adopted. ${ }^{11}$ Strong foundations had already been laid in the inter-war period and were strengthened in wartime in Britain and the USA. ${ }^{12}$ In the Cold War era, a strong social democratic movement was widely seen as a vital bulwark against the spread of communism. ${ }^{13}$

At a somewhat less meta-theoretical level, a range of contemporary accounts within the political economy and employment relations literature suggests that not only has the position of workers and their representatives been worsening for many years, and markedly so in the period following the oil price shock of the mid-1970s, but also that such trends are very difficult or impossible to reverse. ${ }^{14}$ In the Twenty-First Century, trade union density in Britain is reverting to its position a century ago, arguably its secular mean. ${ }^{15}$ This reflects the extraordinary strengthening of capital during the "third wave" of globalization, forcing all countries onto a neo-liberal path. Even more pessimistic variations of this point of view suggest that the ultimate outcomes may be large scale starvation, authoritarianism and war. ${ }^{16}$ 


\section{Relative prosperity and elites}

A second point of view would be that tripartite compromises reflect changes in élite composition and/or strategies which, in turn, are conditioned by overall economic growth. Elite composition approaches encompass the work of Priestland and recent work by Karel Williams and colleagues at Manchester. ${ }^{17}$ These theories draw on a strong historical patrimony developed by Barrington Moore Jr who famously documented the historic linkages between governing bourgeoisies and democratic institutions in major economies, noting the significance of the absence of both. ${ }^{18}$ Priestland assumes that élites tend to be divided between merchant/capitalists, militarists and intellectuals. ${ }^{19}$ Only when the latter are in leadership - which is only likely to occur when the former two groups have succeeded in utterly exhausting and discrediting themselves - are class compromises likely.

Williams and colleagues focus on the extent to which in recent years financial interests may capture policy-making processes and are able to exert influence largely independent of democratic constraints. ${ }^{20}$ Wood and Lane argue that during periods of economic crisis, owners of highly fungible assets are likely to assume predominance over more patient investors, and those with sunk capital (traditional managers and workers) within the firm. ${ }^{21}$ The argument finds historic underpinning from the differential support that diverse élite groups afforded Nazism in inter-war Germany. ${ }^{22}$ Wood and Lane reject the view that the present age represents a return to rentier power, however, as investors with highly fungible assets include sovereign wealth funds (SWFs), who are opening up a new type of statism which simply bypasses corporatist arrangements. In most cases, behaviour will not be far removed from that of traditional rentiers. ${ }^{23}$ However, some SWFs, most notably Norway's, pursue a social agenda that might be conducive to compromise at firm, but not at societal level. Others encompass thinly-veiled foreign policy ambitions, which have little to do with traditional firm practice. However, the picture is a far from uniform one as labour stakeholders do tend to encourage dialogue or compromise with worker interests at firm level. ${ }^{24}$

An important new book by Piketty presents a somewhat different viewpoint. ${ }^{25}$ Piketty is, in common with theorists of near-inevitable labour coercion, somewhat skeptical as to the possibilities of meaningful class compromises other than in very particular circumstances. However, in his study of wealth spanning the last three centuries, he argues that in hard economic times, societal inequality has risen as élites concentrate their resources in speculative rather than productive investment. In contrast, in times of growth such as the thirty-year post-war boom, the societal base of consumption widens, making more productive investment attractive; this, in turn, increases workers' bargaining power, encouraging class compromise. As the rate of return on financial assets invariably exceeds the rate of growth, when, as in the present, growth is low, social inequality widens. ${ }^{26}$ This makes for further concentration of wealth and power in the hands of élites, reducing the likelihood of social compromises.

\section{Tripartism and scale}

A limitation of the preceding sets of arguments is that they are, above all, temporal theories, linking the relative power of societal groupings to long-term shifts in the nature of capitalism in the advanced economies. A central reference point for much of the literature on comparative capitalism has been developed and relates in particular to in particular, coordinated markets - the Rhineland economies and Scandinavia - where stakeholder rights are relatively strong. As firms are bound by dense or "thick" ties to a 
range of societal interests, mirrored by societal level institutions, they are founded on longterm compromises and ongoing reconstructive deals between state, business and labour. ${ }^{27}$ These societies, in which tripartism is a more or less 'natural' state of affairs, remain an analytic reference point that stands in sharp contrast to that of the Anglo-Saxon model. Yet current theories of comparative capitalism highlight the extent to which very different types of capitalism, with quite distinct forms of societal relations (and not simply the Rhineland or Anglo-Saxon forms) may coexist in different national settings across the globe. ${ }^{28}$ This would suggest that tripartite deals are possible across a much wider range of contexts internationally than has often been assumed.

The post-2008 economic crisis reopened debate as to the relative embeddedness of national institutions, and the degree of 'path dependence' to be found in different national settings. Pessimistic accounts, such as that of Streeck, suggest that broad historical trends towards the dissolution of non-financial ties ultimately over-ride distinct national historical legacies, leading to the gradual unravelling of more coordinated types of capitalism. ${ }^{29}$ In contrast, and informed by the radical economic geography literature, 'variegated capitalism' approaches highlight the tensions between a global capitalist ecosystem, and nation-specific forms of institutional mediation. ${ }^{30}$ Thus, social democratic régimes on the 'global periphery' have proven capable of building institutional frameworks that incorporate labour via tripartite mechanisms and which have also been associated with a degree of economic success. ${ }^{31}$ In Russia, an alternative specific form of 'social partnership' persists, reflected in an agreement with the International Labour Organisation, dubbed 'coercive corporatism', which also embodies weak forms of tripartism. $^{32}$

In practical terms, it can further be argued that supra-national and national institutions are at best loosely coupled. Consequently, for example, the seemingly overwhelming power of international financial institutions varies greatly from setting to setting; many Asian nations and Russia sought to stockpile foreign exchange reserves in the aftermath of the Asian financial crisis, precisely to avoid having to accept IMF policy prescriptions in the future. Moreover, the uneven and declining nature of US influence has ensured that the political evangelization of neo-liberalism has been decreasingly well-received. Finally, as Morgan notes, Multi-National Enterprises choose to invest in countries for a range of reasons, from natural resources through market access to a desire to benefit from particular local production regimes. ${ }^{33}$ The relative draw of these factors (and, in particular, the relative strength of the latter) will, in turn, impact on the extent to which firms make strategic compromises and associated adjustments in organizational practices according to setting. All this would suggest that some national governments have much more power - and, indeed, greater incentives - to engage in tripartite deals, than others. In the case of Western companies purchasing goods from low-wage countries, as we illustrate below, they have responded to concerns by ethical investors, consumer opinion and other companies to push developing-world governments for, and to participate in tripartite deals.

This might suggest closer examination of the historic development of types of capitalism across the world and how it has conditioned corporatist arrangements such as tripartism. Study of the Latin American experience suggests the importance of political conjunctures within the state construction process which gave rise to such weak tripartite phenomena as Peronism in Argentina; more recent conjunctures have also evoked similarly labour-oriented state responses with complementary inputs sought from other civil society actors. ${ }^{34}$ Recent analyses have stressed the relationship between institutionalization and economic segmentation outside of the advanced economies. 
Although there have been numerous attempts to categorize emerging markets around the world into distinct capitalist archetypes - for example, Hierarchical Market Economies and Segmented Business Systems - a common strand in such categorizations is of structural internal economic divides, and uneven institutional coverage. ${ }^{35}$ Although democratic transitions - for example those which followed immediately on from African independence in the 1960s or the post-Apartheid transition in South Africa - may encourage tripartite deal making, such deals tend to be somewhat short-lived. Whilst organized business may initially favour arrangements of this type to secure stability through transitions, a bedding-down of the new order means that compromises are invariably challenged at the expense of workers' organisations. When such deals retain their form, uneven regulation and enforcement may result in limited coverage. This does not mean however that tripartism has entirely disappeared even in these countries, nor does it remove it as a viable option elsewhere.

Structures are reconstituted and remoulded through actors' strategic choices. Although a favourable social, economic and political environment may allow more room for novelty and creativity in such choices, even in bleak times, the possibility and type of social compromise at least in part reflects decisions by unions and other social actors. This does not mean that an optimal set of best practices for unions exists that is readily transposable between contexts and periods, as has been highlighted by the very mixed record of organizing unionism outside of California. However, political actions within and in support of tripartite mechanisms by some trade union movements in Latin America were pursued with success during the democratic transitions at the end of the Twentieth Century and, as Sandbrook and colleagues demonstrate, in other settings where popular movements have acted in concert with unions to pressure élites. ${ }^{36}$ Thus, the contemporary situation at global level is one of the uneven application of weaker forms of tripartism.

\section{Variations in tripartism: evidence from around the world}

Tripartism remains a set of arrangements that is integral to the 'European model' of industrial relations. ${ }^{37}$ Three of the articles published here make significant contributions to the transnational history of European tripartism in the comparative and supra-national meanings of the 'transnational' term. ${ }^{38}$ Chris Minns and Marian Rizov operate on a broad temporal and spatial canvas to examine tripartism's impact on wage moderation and dispersion since 1970. They show that, notwithstanding the importance of national institutional effects, government involvement in wage bargaining generally led to increased wage moderation and reduced wage dispersion across the countries they investigated, and that this effect persisted even when the institutional basis for it was eroded or disappeared. The return to Belle Epoque levels of social inequality in many of the advanced societies vests this finding with particular importance; tripartite deal-making around wages and related conditions of work, at least in this period, represented a proven policy mechanism for promoting greater equity - and a more sustainable basis for consumption - without entering unchartered policy waters. Moreover, not only did these arrangements encourage wage moderation; they also created the conditions for enhanced productivity in manufacturing industry, a lesson that present-day Britain, with stagnant or declining wages for the bulk of the population, and stagnating productivity rates might heed. Centralised bargaining did not, as some industrial relations researchers have suggested, lead to relatively large increases for union members but rather created 'concertina' effects. Tripartism was in this sense part of a virtuous circle in the period 
which continued to have lingering and positive consequences even well after the Golden Age itself ended.

Thomas Prosser and Emmanuelle Perrin contribute an article on the historical development of tripartism at the EU level which tends to confirm the strong reservations some scholars have expressed on the effectiveness of this level of 'social dialogue'. 39 Their article examines the 'new phase' of the European social dialogue's credentials as a system of European tripartism, judging it against four essential criteria. They concur with De Boer et al. on its broadening and de-intensification; though the 'new phase' of the social dialogue has broached innovative topics, its outputs are peripheral and its implementation patchy. Prosser and Perrin reflect on the difficulties associated with transnational tripartism and the increasing dilution of the European social dialogue, especially in the aftermath of the financial crisis. One especially interesting aspect of the article is the backlight that it throws on the national history of tripartism: its marginality, weak and piecemeal implementation has represented little impediment to tripartism's persistence. In other words, challenges to the social model in Europe co-exist with remarkably persistent specific features. Again, pressures to develop pan-Eurozone governance features may create a new political space for new forms of tripartism, even if the prospect seems relatively remote at the time of writing.

Guglielmo Meardi, Juliusz Gardawski and Oscar Molina adopt a comparative transnational historical approach to compare the evolution of weakly-institutionalised forms of tripartism subsequent on transitions to democracy (soon followed by European Union integration) in Spain and Poland, showing the referential significance of the former case for the latter. Despite widespread criticism of tripartism's functioning in both cases, the authors concur with Hassel's more measured estimation of these arrangements' function in 'Eastern' Europe. ${ }^{40}$ The authors argue for Tripartism's stabilizing and 'foundational' function and point out the arrangements' longevity in both national cases. While certain structural constraints are identified by the authorial team, the durability of these limited forms of tripartism appear to illustrate its functionality and certainly show its viability in rather diverse national contexts with very distinctive historical legacies.

Jimmy Donaghey and Paul Teague review the rise and fall of the Irish experiment in social partnership. Initially, it led to a "benign" period of productivity-driven growth. Foreign manufacturing multinationals operating in Ireland provided an engine for the revival of manufacturing, but nonetheless did not generate pressures for better and more supportive institutions, as they could draw on their own internal capabilities. Moreover, they were drawn to Ireland for reasons (such as a favourable tax régime and market access) that had little to do with the national production régime, and had few incentives to reform or deepen the latter. Ultimately, the increased stranglehold of financial services on the Irish economy undermined the partnership's functionality; returns from financial speculation eclipsed what could be accrued from deploying capital productively and the social compromises this may have entailed. This made it easy for employers and the state to abandon it during the 2008 economic crisis, ironically making any move to a more balanced economy more difficult.

Two further articles published here deal with extra-European manifestations of tripartism. Bernard Gann, David Morgan and Peter Sheldon explore the development of Singaporean tripartism. This reflected the desire of government to bolster its social legitimacy and foster growth whilst marginalizing political opposition; the subordination of organized labour was achieved through inclusion. The emerging order was built on traditional cultural values and the desire for social cohesion: the resultant system of "enforceable benevolence" brought with it both economic and social advances, but these 
were linked with political developments that were very different from the post-war social democracies of Europe. As is the case with corporatism, tripartism does not necessarily rest on fully democratic institutions; rather, it can serve as a policy tool to help facilitate social stability and hence, diminish pressures for radical political reform. Given that gross social inequality is ultimately difficult to sustain without constant war or repression, this is a lesson that many current Western governments might heed.

Geoffrey Wood, Gilton Klerk and Pauline Dibben contribute on Southern Africa where Namibia, Mozambique and South Africa all experimented with tripartite initiatives during the democratization period. Whilst in all instances this brought secure and significant improvements in worker rights, relative enforceability reflected variations in state capabilities and political will. Ultimately, none of the experiments brought about the far-reaching class compromises which many believe are ultimately necessary to secure social stability in these societies characterized by extraordinarily high levels of social inequality. The authors ascribe this to neo-liberalism's policy hegemony, shifting élite composition (with the rise of political entrepreneurs once liberation had been secured), dominant partyism, and the extent to which rising commodity prices have removed urgency from the need to find economic solutions. However, mineral price volatility and the often negative effects growth in mineral extraction has elsewhere in national economies underscores the relevance of a type of social compromise that has been, in other contexts, associated with superior levels of equality and productivity.

Notwithstanding these substantial contributions, and despite widespread and insistent advocacy of 'trans-national' history, a particularly significant lacuna remains in the history of tripartism: the historical role of the ILO and its interactions with other international and national-level actors. ${ }^{41}$ The ILO's foundation as the first tripartite international body gave institutional embodiment to the concept at global level. Yet in common with other international organizations the ILO itself has felt constrained by current views of labour rights and its web of external relationships from elaborating on its own successes in the area. $^{42}$

The ILO's activities in support of tripartism, including how they were received by and impacted upon national collective institutions certainly require further research, which may be co-ordinated under the umbrella of the ILO's centenary history project. ${ }^{43}$ Until 1939, the ILO was a largely developed-world institution principally concerned with advancing employee welfare, cautious and bounded advocacy of collective institutions including in the colonial world and consolidating its own legitimacy. ${ }^{44}$ In the post-war period, its internal organization and the wider context meant that it could play a significant role in developing tripartism. It has been argued that its influence-and its emphasis on tripartism with it-declined greatly from the early 1980s essentially because of a major environmental shift: recession, the rise of neo-liberalism, and US global hegemony. Structural Adjustment Programmes and the resultant expansion of informal sectors all rendered institutional industrial relations less significant. ${ }^{45}$ Standing has argued that these developments brought an inadequate response from the ILO, suggesting that it lost influence in relation to the international financial bodies and essentially abandoned tripartism in favour of the 'Decent Work' agenda. ${ }^{46}$

The view threatens to obscure important aspects of the ILO's recent work and thereby diminish interest in examination of its long-standing role in advocating and implementing tripartism. Tripartite institutions were created at both micro- and macro-level in several developing countries in the $21^{\text {st }}$ Century. ${ }^{47}$ As we have suggested above, some function remained for many forms of the institution, fuelled by increased demand for regulation by some developed country companies seeking to reduce reputational risk in their supply 
chains, a demand that has increased since the Rana Plaza disaster. ${ }^{48}$ A higher contemporary profile for its activities seems likely to stimulate further investigation of its many-sided historic role.

\section{Conclusion: persistent and uneven tripartism}

A common theme across the papers in this collection is that whilst ambitious neocorporatist deal making may be difficult to replicate, tripartism remains possible and, indeed, tripartite experiments continue regularly to manifest themselves in a wide range of different settings, a phenomenon that has been particularly evident outside of the betterknown cases in European countries. This reflects a second feature of tripartism highlighted in the collection: tripartite deals have varied greatly in content, scope and durability according to historical and indeed national circumstances. In the case of Singapore, the relative policy autonomy of national government vis-à-vis external players allowed some scope for deal-making with the aim of helping secure the national policy objectives of political and economic sustainability. In the case of the countries of Southern Africa, strong pressures militated towards deal making at a time when the transition to democracy was uncertain and fragile, but an aggressive counter-movement by employers and their allies in government occurred once stability had been secured.

The prospects of tripartite deal-making are shaped by powerful international forces. However, it is possible to over-estimate the power of international financial institutions and MNEs, and under-estimate the need for supra-national legitimacy and stability. Whilst by no means a rare feature of social life, the economically beneficial effects of social instability and war are restricted to tiny élite factions, giving many business interests and other societal actors a real interest in alternatives.

Thus, we argue that although tripartism's heyday is clearly past, it remains a viable option and its history is therefore relevant both as a significant historic manifestation of social compromise and as a massive and diverse repository of experience. Whilst, as we and our contributors have argued, lacunae undoubtedly remain, the contributions in this special edition constitute a considerable step forward in enlarging the stock of historical knowledge on which actors may draw. As in relation to previous epochs, a very real risk exists of imparting a determinist analysis to the present and apparently endless economic crisis. Whilst neo-liberalism may have proved remarkably durable, its difficulties with economic realities notwithstanding (as it is, after all, primarily a vehicle for elite enrichment), this does not mean that the public space for debating new ideas, or the possibility for political action and the adoption of meaningful alternatives, have disappeared. As the experience of different forms of tripartism around the world demonstrates, it remains possible even in very difficult circumstances, to bring about compromises that help secure political and economic sustainability, greater social equity, and, higher productivity than might otherwise have seemed possible.

\section{Notes}

1. Hassel, "The politics of social pacts"; Hassel, "Policies and politics in social pacts"; Regini, "Tripartite concertation"; Siegel, "Social pacts revisited"; Brandl, "Successful wage concertation"

2. Regini, "Tripartite concertation"; Thelen, "Institutional change"

3. Spiegel, "Revising the Past".

4. Middlemas, Politics in Industrial Society.

5. Harvey, "Neo-Liberalism". 
6. Dryzek and Goodin, "Risk-Sharing and Social Justice"; Baldwin, Politics of Social Solidarity, 3-4.

7. Boyer, "How do Institutions Cohere".

8. Arrowsmith and Pulignano, Transformation of Employment Relations in Europe.

9. Calhoun and Lence, Union and Liberty.

10. Hirschmann and Hill, "On human commodification".

11. Middlemas, Politics in Industrial Society.

12. Ibid.

13. Campbell et al., "Post-war Compromise".

14. Mcllroy and Croucher, "British Trade Unions".

15. Gospel, "Representing workers in Britain".

16. Sewell, "Temporalities of Capitalism".

17. Priestland, Merchant, Soldier, Sage; Engelen et al., After the Great Complacence.

18. Barrington Moore Jr, Social Origins of Dictatorship and Democracy, and Injustice.

19. Priestland, Merchant, Soldier, Sage.

20. Engelen et al., After the Great Complacence.

21. Wood and Lane, "Institutions, Change and Diversity", 20-21.

22. Braun, German Economy.

23. Ibid.

24. Agrawal, "Corporate Governance Objectives".

25. Piketty, Capital in the Twenty-First Century.

26. Ibid.

27. Deeg and Jackson, "Dynamic Theory of Capitalist Diversity".

28. Wood and Lane, "Institutions, Change and Diversity"; Wood et al.,"Comparative Capitalism without Capitalism".

29. Streeck, Reforming Capitalism.

30. Jessop, "Diversity and Variability of Capitalism".

31. Sandbrook et al., Social Democracy in the Global Periphery.

32. Schwartz and McCann, "Overlapping effects".

33. Morgan, "International Business".

34. Chalmers et al., New Politics of Inequality in Latin America.

35. Hancké et al., "Introduction"; Wood and Frynas, "Institutional Basis of Economic Failure".

36. Cook, "Towards Flexible Industrial Relations"; Sandbrook et al., Social Democracy in the Global Periphery.

37. Arrowsmith and Pulignano, Transformation of Employment Relations in Europe.

38. Croucher and McIlroy, "Introduction: Beyond National History".

39. See, for example, De Boer et al., "European Social and Sectoral Dialogue"; Keller and Weber, "Sectoral Social Dialogue".

40. Hassel, "Policies and Politics in Social Pacts".

41. McIlroy and Croucher, "British Trade Unions".

42. Australian Government, Multilateral Assessment: ILO.

43. Van Daele, "International Labour Organisation in Research".

44. Haworth et al., "International Labour Standards Regime".

45. Simpson, "ILO and Tripartism"; Rodgers et al., "International Labour Organization"; Haworth et al., "International Labour Standards Regime"; Stiglitz, Globalization and its Discontents; ILO, National Tripartite Social Dialogue.

46. Standing, "The International Labour Organization".

47. See, for example, Adler et al., "Interim Institutions and the Development Process"; Di Caprio, "Demand Side of Social Protection".

48. Islam and McPhail, "Regulating for Corporate Human Rights Abuses"; Di Caprio, "Demand Side of Social Protection".

\section{References}

Adler, D., C. Sage, and M. Woolcock. "Interim institutions and the development process: opening spaces for reform in Cambodia and Indonesia." Brooks World Poverty Institute Working Paper, University of Manchester, 2009. 
Agrarwal, A. K. "Corporate governance objectives of labor union shareholders: evidence from proxy voting." Review of Financial Studies 25, no. 1 (2012): 187-226.

Arrowsmith, J., and A. Pulignano. The transformation of employment relations in Europe: institutions and outcomes in the era of globalization. London: Routledge, 2013.

Australian Government. Australian Multilateral Assessment: ILO. Commonwealth of Australia 2012.

Baldwin, P. The Politics of Social Solidarity. Cambridge: Cambridge University Press, 1990.

Boyer, R. "How do Institutions Cohere and Change." In Institutions and Working Life, edited by G. Wood, and P. James, 13-61. Oxford: Oxford University Press, 2006.

Brandl, B. "Successful wage concertation: the economic effects of wage pacts and their alternatives." British Journal of Industrial Relations 50, no. 3 (2012): 482-501.

Braun, H. J. The German Economy in the Twentieth Century. London: Routledge, 1990.

Calhoun, J. C., and R. M. Lence. Union and Liberty: The Political Philosophy of John C. Calhoun. Indianapolis: Liberty Fund Inc., 1992.

Campbell, A., N. Fishman, and J. McIlroy. "The post-war compromise: mapping industrial politics 1945-64." In The Post-War Compromise. British trade unions and industrial politics 1945-64, edited by A. Campbell, N. Fishman, and J. McIlroy, 69-113. London: Merlin Press, 2007.

Chalmers, D. A., Vilas, C. M., Martin, S. B., Pinester, C., and Segarra, M., eds. The new politics of inequality in Latin America: re-thinking participation and representation. Oxford: Oxford University Press, 1997.

Cook, M. L. "Towards flexible industrial relations? Neo-liberalism, democracy and labour reform in Latin America." Industrial Relations. A Journal of Economy and Society 37, no. 3 (1998): $311-336$.

Croucher, R., and J. McIlroy. "Introduction: beyond national history." Labor History 54, no. 5 (2013): 485-490.

De Boer, R., H. Benedictus, and M. van der Meer. "Broadening without intensification. The added value of the European social and sectoral dialogue." European Journal of Industrial Relations 11, no. 1 (2005): 51-70.

Deeg, R., and G. Jackson. "Towards a more dynamic theory of capitalist diversity." Socio-Economic Review 5, no. 1 (2007): 149-180.

Di Caprio, A. "The demand side of social protection: lessons from Cambodia's labour rights experience." World Development 48 (2013): 108-119.

Dryzek, J., and R. Goodin. "Risk-Sharing and Social Justice: The Motivational Foundations of the Post-War Welfare State.” British Journal of Political Science 16, no. 1 (1986): 1-34.

Engelen, E., I. Ertürk, J. Froud, S. Johal, A. Leaver, M. Moran, A. Nilsson, and K. Williams. After the Great Complacence. Oxford: Oxford University Press, 2011.

Gospel, H. "Representing workers: trade union recognition and membership in Britain." In Representing workers: trade union recognition and membership in Britain, edited by H. F. Gospel and S. Wood, 1-14. London: Routledge, 2003.

Hancké, B., and M. Thatcher. "Introduction." In Beyond varieties of capitalism: conflict, contradiction, and complementarities in the European economy, edited by B. Hancké, M. Rhodes, and M. Thatcher, 3-38. Oxford: Oxford University Press, 2007.

Harvey, D. "Neo-Liberalism as Creative Destruction." Annals of the American Academy of Political and Social Science 610, no. 1 (2007): 21-44.

Hassel, A. "Policies and politics in social pacts in Europe." European Journal of Industrial Relations 15, no. 1 (2009): 7-26.

Hassel, A. "The politics of social pacts." British Journal of Industrial Relations 41, no. 4 (2003): $707-726$.

Haworth, N., S. Hughes, and R. Wilkinson. "The international labour standards regime: a case study in global regulation." Environment and Planning A 37, no. 11 (2005): 939-1953.

Hernández Alvarez, Oscar. "Latin America." In Towards Social Dialogue: Tripartite Cooperation in national economic and social policy-making, edited by A. Trebilcock, 335-370. Geneva: ILO, 1994.

Hirschman, E. C., and R. P. Hill. "On human commodification: a model for African-American slavery." Advances in Consumer Research 26 (1999): 394.

ILO. National tripartite social dialogue: an ILO guide for improved governance. International Labour Office, Social Dialogue and Tripartism Unit, Governance and Tripartism Department. Geneva: ILO, 2013. 
Islam, M. A., and K. McPhail. "Regulating for corporate human rights abuses: the emergence of corporate reporting on the ILO's human rights standards within the global garment manufacturing and retail industries." Critical Perspectives on Accounting 22, no. 8 (2011): $790-810$.

Jessop, B. "Rethinking the Diversity and Variability of Capitalism: on Variegated Capitalism in the World Market." In Institutions, Internal Diversity and Change, edited by C. Lane and G. Wood, 209-237. London: Routledge, 2012.

Keller, B., and S. Weber. "Sectoral social dialogue at European level: problems and prospects of implementation." European Journal of Industrial Relations 17, no. 3 (2011): 227-243.

McIlroy, J., and R. Croucher. "British trade unions and the academics: the case of Unionlearn." Capital and Class 37, no. 2 (2013): 263-284.

Middlemas, K. Politics in Industrial Society. London: André Deutsch, 1979.

Moore, B. Jr. Injustice: the social basis of obedience and revolt. White Plains. New York: M.E. Sharpe, 1978.

Moore, B. Jr.. Social Origins of Dictatorship and Democracy: Lord and Peasant in the Making of the Modern World. Boston: Beacon Press, 1966.

Morgan, G. "International Business, Multinationals and National Business Systems." In Handbook of Institutional Approaches to International Business, edited by G. Wood and M. Demirbag, 18-40. Cheltenham: Elgar, 2012.

Piketty, P. Capital in the Twenty-First Century. Cambridge, Mass: Belknapp Press, 2014.

Priestland, D. Merchant, Soldier, Sage: A New History of Power. London: Fontana, 2012.

Regini, M. "Tripartite Concertation and Varieties of Capitalism." European Journal of Industrial Relations 9, no. 3 (2003): 251-263.

Rodgers, G., E. Lee, L. Swepston, and J. Van Daele. The International Labour Organization and the quest for social justice, 1919-2009. Geneva: ILO, 2009.

Sandbrook, R., M. Edelman, P. Heller, and J. Teichman, eds. Social Democracy in the Global Periphery. Origins, Challenges, Prospects. Cambridge: Cambridge University Press, 2007.

Schwartz, G., and L. McCann. "Overlapping effects: Path dependence and path generation in management and organization in Russia." Human Relations 60, no. 10 (2007): 1525-1550.

Sewell, W. "The Temporalities of Capitalism." Socio-Economic Review 6, no. 3 (2008): 517-537.

Siegel, N. A. "Social Pacts Revisited: 'Competitive Concertation' and Complex Causality in Negotiated Welfare State Reforms." European Journal of Industrial Relations 11, no. 1 (2005): $107-126$.

Simpson, W. R. "ILO and Tripartism: Some Reflections." Monthly Labour Review 117 (1994): $40-46$.

Spiegel, G. M. "Revising the past/revisiting the present: how change happens in historiography." History and Theory 46, no. 4 (2007): 1-19.

Standing, G. "The International Labour Organization." New Political Economy 15, no. 2 (2010): 307-318.

Stiglitz, J. Globalization and its Discontents. New York: Norton, 2002.

Streeck, W. Reforming Capitalism: Institutional Change in the German Political Economy. Oxford: Oxford University Press, 2009.

Thelen, K. "Institutional change in advanced political economies." British Journal of Industrial Relations 47, no. 3 (2009): 471-498.

Van Daele, J. "The International Labour Organisation in Past and Present Research." International Review of Social History 53, no. 3 (2008): 485-511.

Wood, G., P. Dibben, and S. Ogden. "Comparative Capitalism without Capitalism, and Production without Workers: The Limits and Possibilities of Contemporary Institutional Analysis." International Journal of Management Reviews. DOI:10.1111/ijmr.12025, early version online at http://onlinelibrary.wiley.com/doi/10.1111/ijmr.12025/abstract (2014):.

Wood, G., and G. Frynas. "The Institutional Basis of Economic Failure: Anatomy of the Segmented Business System." Socio-Economic Review 4, no. 2 (2006): 239-277.

Wood, G., and C. Lane. "Institutions, Change and Diversity." In Capitalist Diversity and Diversity within Capitalism, edited by C. Lane and G. Wood, 1-31. London: Routledge, 2012. 